\title{
Factors affecting utilization of cervical cancer prevention services in low-resource settings
}

Allison Bingham, PhD, ${ }^{(1)}$ Amie Bishop, MSW, MPH, (1) Patricia C offey, MPH, PhD, (1) Jennifer W inkler, MPH, (1) Janet Bradley, MA, (2) Ilana D zuba, MHS, ${ }^{(2)}$ Irene Agurto, PhD. ${ }^{(3)}$

\section{Bingham A, Bishop A, Coffey P,W inkler J, Bradley J, Dzuba I, Agurto I. Factors affecting utilization of cervical cancer prevention services in low-resource settings. Salud Publica Mex 2003;45 suppl 3:S408-S416. This paper is available too at: http://www.insp.mx/salud/index.html}

\begin{abstract}
A bstract
Strategies for introducing or strengthening cervical cancer prevention programs must focus on ensuring that appropriate, cost-effective ser vices are available and that women who most need the services will, in fact, use them. This article summarizes the experiences of research projects in Bolivia, Peru, Kenya, South Africa, and Mexico. Factors that affect participation rates in cervical cancer prevention programs are categorized in three sections. The first section describes factors that arise from prevailing sociocultural norms that influence women's views on reproductive health, well being, and notions of illness. The second section discusses factors related to the clinical requirements and the type of service delivery system in which a woman is being asked to participate.The third section discusses factors related to quality of care. Examples of strategies that programs are using to encourage women's participation in cervical cancer prevention services are provided. This paper is available too at: http://www.insp.mx/salud/index.html
\end{abstract}

Key words: cervix neoplasms/prevention and control; patient participation; quality of health care

\author{
Bingham A, Bishop A, Coffey P,W inkler J, \\ Bradley J, Dzuba I,Agurto I. \\ Factores determinantes de utilización de programas de detección \\ oportuna de cáncer cervical en población de bajos recursos. \\ Salud Publica Mex 2003;45 supl 3:S408-S416. \\ Este artículo también está disponible en: \\ http://www.insp.mx/salud/index.html
}

\section{Resumen}

Las estrategias para introducir o fortalecer programas de prevención de cáncer cervical deben enfo carse hacia garantizar servicios costo-efectivos, que se encuentren disponibles para que las mujeres que los necesiten puedan utllizarlos. Este artículo resume la experiencia de proyectos de investigación realizados en Bolivia, Perú, Kenya, Sudáfrica y México. Los factores que afectan la tasa de participación en programas de prevención son categorizados en tres secciones. La primera describe los factores que surgen predominantemente por normas socioculturales que influyen en la visión que las mujeres tienen sobre la salud reproductiva. La segunda discute los factores relacionados con los requerimientos clínicos y el tipo de servicio ofrecido, así como el sistema mediante el cual las mujeres están siendo invitadas a participar. La tercera sección discute factores relacionados con la calidad de la atención. Finalmente, se proveen ejemplos de las estrategias sobre los programas que son utilizados para alentar la participación de las mujeres en los servicios de prevención del cáncer cervical. Este artículo también está disponible en: http://www.insp.mx/ salud/index.html

Palabras clave: neoplasmas del cuello uterino/prevención y control; participación de la paciente; calidad de la atención de salud

This work is part of the Alliance for Cervical Cancer Prevention (ACCP), funded by the Bill \& Melinda Gates Foundation.

(1) Program for Appropriate Technology in Health (PATH). Seattle, USA.

(2) EngenderHealth.

(3) Pan American Health O rganization (PAHO).

Received on: 0 ctober 2,2002 - Accepted on: February 17,2003

Address reprint requests to: Dra Allison Bingham. Program for A ppropriate Technology in Health. 1455 N W Leaty W ay, Seattle,W A 98107. USA. E-mail: abingha@ path.org 
0 ver the past decade, the global health community has been giving increased attention to the importance of addressing cervical cancer prevention where the disease burden is greatest. In low-resource settings, important clinical strides are being made in identifying alternative approaches to Pap screening, including methods based on visual inspection of the cervix and on testing for the human papillomavirus (HPV) ${ }^{1-3}$ While still experimental, visual approaches present women in poor regions with the possibility of access to effective screening, and to treatment for precancerous conditions, if needed..$^{4-6}$ Similarly, new technologies designed to improve screening accuracy, such as liquid-based cytology, are being implemented to strengthen current cytology-based programs, particularly in Latin America and the Caribbean. ${ }^{7-10}$ Furthermore, a number of countries have been reevaluating elements of their national prevention strategies, such as the recommended screening age parameters and frequencies, in an effort to ensure both screening coverage of women most at risk and efficient use of available resources. ${ }^{11,12}$

Strategies for introducing or strengthening cervical cancer prevention programs must focus on ensuring that appropriate, cost-effective services are available and that women who most need the services will, in fact, use them. ${ }^{13}$ A growing body of international research has shown that if these goals are not realized, cervical cancer prevention programs will not achieve the necessary levels of coverage that are required to reduce the overall disease burden. ${ }^{1,11,14}$

A number of factors may affect a woman's ability and desire to participate in cervical cancer prevention programs, and the impact of a woman's decision-making process cannot be ignored. It is therefore essential that cervical cancer prevention efforts eliminate the most critical barriers that affect women's participation, as well as identify and foster conditions that support their use of services.

This article summarizes the experiences of selected Alliance for Cervical Cancer Prevention (ACCP)*

\footnotetext{
* The ACCP is a group of five international organizations with a shared goal of working to prevent cervical cancer in developing countries. Alliance partners include EngenderHealth, a family planning and reproductive health agency; International Agency for Research on Cancer (IARC); JHPIEGO Corporation, a reproductive health agency affiliated with Johns Hopkins University; Pan American Health Organization (PAHO); and Program for Appropriate Technology in Health (PATH). Alliance projects focus on regions in which cervical cancer incidence and mortality are highest: sub-Saharan Africa, Latin America, and South Asia. The projects described here were funded by the Bill \& Melinda Gates Foundation through the Alliance for Cervical Cancer Prevention.
}

research projects in Bolivia, ${ }^{*}$ Peru, ${ }^{15,16}$ Kenya, ${ }^{17,18}$ and South Africa, ${ }^{2,19-21}$ as well as two studies ${ }^{22,23}$ that preceded current ACCP project efforts. Factors that affect participation rates in cervical cancer prevention programs are categorized in three sections. The first section describes factors that arise from prevailing sociocultural norms that influence women's views on reproductive health, well-being, and notions of illness. The second section discusses factors related to the clinical requirements and the type of service delivery system in which a woman is being asked to participate. The third section discusses factors related to quality of care. Examples of strategies that programs are using to encourage women's participation in cervical cancer prevention services are provided.

\section{Material and Methods}

Tables I and II summarize the ACCP projects that are the primary sources of information for this article. Table II lists special studies being carried out within these projects and relevant citations. Data also are presented from two other sources: a) a PAHO-funded study that PATH conducted with the Government of Mexico to understand knowledge, attitudes, and practices regarding cervical cancer, its detection and treatment, and perceived barriers to care among woman aged 35 to 64 and among providers in four different regions of $\mathrm{Na}-$ yarit, Mexico ${ }^{22}$ and b) a PAHO-supported review of qualitative research efforts that examined barriers and benefits of Pap smear screening as perceived by women in Mexico, Ecuador, Venezuela, Peru, and El Salvador. ${ }^{23}$

\section{Results}

\section{Factors related to sociocultural norms}

Beliefs and attitudes towards the concept of prevention. The projects we reviewed are being undertaken in settings where people tend to seek allopathic health care as a last resort (for example, when home-based or traditional interventions fail) and where understanding of prevention is sometimes limited. For example, women interviewed in Kenya reported that it is often problematic for a woman to go to a health clinic to be screened if she is "feeling healthy," as she must convince her partner to get money for transport when she is not vis-

\footnotetext{
* Bolivia Ministry of Health, EngenderHealth, Pan American Health Organization. Los servicios de prevención y control de cáncer del cuello del útero: Un diagnóstico estratégico, Informe final. Unpublished report available from EngenderHealth, New York.
} 
Table I

\section{List of ACCP CERVICAL CANCER PREVENTION RESEARCH AND DEMONSTRATION PROJECTS AND RELATED PROGRAM INFORMATION}

\begin{tabular}{|c|c|c|c|c|}
\hline $\begin{array}{l}\text { Alliance partner/ } \\
\text { Name of project }\end{array}$ & Project location/Project type & Service delivery model & $\begin{array}{l}\text { Target age group/ Size of } \\
\text { eligible population }\end{array}$ & Client participation strategies \\
\hline $\begin{array}{l}\text { EngenderH ealth } \\
\text { Safety and Efficacy of Cryo- } \\
\text { surgery when used for } \\
\text { "Screen \& Treat" in a Low Re- } \\
\text { source Setting [D enny, et al., } \\
\text { 2000] }\end{array}$ & $\begin{array}{l}\text { South Africa: } \\
\text { Randomized clinical trial of } \\
\text { HPV DN A and VIA in a } \\
\text { peri-urban informal settle- } \\
\text { ment (Khayelitsha, South } \\
\text { Africa). }\end{array}$ & $\begin{array}{l}\text { Screening:VIA or HPV DNA } \\
\text { testing } \\
\text { Treatment: cryotherapy }\end{array}$ & $\begin{array}{l}\text { Women } 35-65 \text { years/ } \\
10000 \text { women }\end{array}$ & $\begin{array}{l}\text { Promotion at health fairs, mes- } \\
\text { sages through local prayer sing- } \\
\text { ers, photocomic, radio play }\end{array}$ \\
\hline $\begin{array}{l}\text { EngenderH ealth } \\
\text { CHIP:The Cervical Health } \\
\text { Implementation Project }\end{array}$ & $\begin{array}{l}\text { South Africa: } \\
\text { Implementation of cervical } \\
\text { screening as part of nation- } \\
\text { al health care services in } \\
\text { South A frica. }\end{array}$ & $\begin{array}{l}\text { Screening: cervical cytology } \\
\text { (Pap) } \\
\text { Treatment: LEEP }\end{array}$ & $\begin{array}{l}\text { Women } 30-60 \text { years/ } \\
\text { A pprox. } 160000 \text { women }\end{array}$ & $\begin{array}{l}\text { Informational and educational } \\
\text { materials distributed at clinics } \\
\text { and in communities }\end{array}$ \\
\hline $\begin{array}{l}\text { EngenderH ealth \& PAHO } \\
\text { Strategic Assessment of } \\
\text { Cervical Cancer Screening } \\
\text { and Treatment Services in } \\
\text { Bolivia (D iagnóstico Es- } \\
\text { tratégico sobre los Servi- } \\
\text { cios de Prevención y } \\
\text { Control de Cáncer de } \\
\text { Cuello Uterino en Bolivia) }\end{array}$ & $\begin{array}{l}\text { Bolivia: } \\
\text { Participatory assessment } \\
\text { to identify how cervical } \\
\text { screening and treatment } \\
\text { might be enhanced to im- } \\
\text { prove reproductive health } \\
\text { in communities. }\end{array}$ & $\begin{array}{l}\text { Screening: cervical cytology } \\
\text { (Pap) } \\
\text { Treatment: conization (knife- } \\
\text { cone, LEEP) hysterectomy }\end{array}$ & $\begin{array}{l}\text { Women } 25-49 \text { years } / 1.5 \text { mil- } \\
\text { lion women in target age } \\
\text { group; } 583 \text { women participat- } \\
\text { ed in assessment }\end{array}$ & $\begin{array}{l}\text { Participation of clients in the as- } \\
\text { sessment process is adapted from } \\
\text { the W HO 3-stage approach to } \\
\text { the Introduction of Contracep- } \\
\text { tive Technologies (Spicehandler J, } \\
\text { Simmons R. Contraceptive Intro- } \\
\text { duction Reconsidered:A Review and } \\
\text { Conceptual Framework. G inebra: } \\
\text { W HO, 1994:1-34.) }\end{array}$ \\
\hline $\begin{array}{l}\text { PAHO \& PATH } \\
\text { TATI:Screening and Imme- } \\
\text { diateTreatment of Precan- } \\
\text { cerous Cervical Lesions } \\
\text { Tamizaje y Tratamiento } \\
\text { Inmediato de Lesiones Pre- } \\
\text { cancerosas Cervicouteri- } \\
\text { nas }\end{array}$ & $\begin{array}{l}\text { Peru: } \\
\text { Service delivery demon- } \\
\text { stration project being con- } \\
\text { ducted in one department } \\
\text { of Peru. }\end{array}$ & $\begin{array}{l}\text { Screening:VIA with cervical } \\
\text { cytology (Pap) (and liquid cy- } \\
\text { tology-based Pap and HPV } \\
\text { on sub-sample) } \\
\text { Confirmation:VIAM or col- } \\
\text { poscopy, biopsy) } \\
\text { Treatment: cryotherapy } \\
\text { [cold-cone, LEEP, and hyster- } \\
\text { ectomy available at tertiary } \\
\text { colposcopy and treatment } \\
\text { centers when cryotherapy } \\
\text { not appropriate] }\end{array}$ & $\begin{array}{l}\text { Women } 25-49 \text { years / } \\
90000 \text { women }\end{array}$ & $\begin{array}{l}\text { - Community promotion teams } \\
\text { that carry out community me- } \\
\text { etings, education sessions, } \\
\text { home visits } \\
\text { - Client-centered quality of care }\end{array}$ \\
\hline $\begin{array}{l}\text { PATH } \\
\text { W KCCPP: Western Kenya } \\
\text { Cervical Cancer Prevention } \\
\text { Project }\end{array}$ & $\begin{array}{l}\text { Kenya: } \\
\text { Service delivery demon- } \\
\text { stration project in three } \\
\text { health clinics and one dis- } \\
\text { trict hospital. }\end{array}$ & $\begin{array}{l}\text { Screening:VIA (with Pap, col- } \\
\text { poscopy, biopsy) } \\
\text { Treatment: cryotherapy }\end{array}$ & $\begin{array}{l}\text { Women } 30-39 \text { years/ } \\
18000 \text { women }\end{array}$ & $\begin{array}{l}\text { - Community health workers } \\
\text { that promote cervical cancer } \\
\text { prevention services } \\
\text { - Client-centered quality of care }\end{array}$ \\
\hline
\end{tabular}

ibly ill. ${ }^{18}$ Furthermore, results from the PAHO analysis of qualitative studies in Latin America and the Caribbean suggest that women generally do not distinguish among types of cancer affecting women's reproductive organs and, therefore, do not readily understand that cervical cancer is a preventable disease. ${ }^{23}$ To address these barriers, several of the ACCP projects have incorporated health promotion messages in prescreening counseling sessions, and outreach and awareness-raising activities among women and communities that provide culturally appropriate discussions about a woman's anatomy and the concept of prevention. ${ }^{16,17,21}$
Beliefs that cervical screening is related to sexually transmitted infections (STI) diagnosis. Many women and their male partners, especially in rural areas, have a limited understanding of female reproductive organs and associated diseases. In many project settings, women sometimes erroneously believe that cervical screening tests also are used to detect STIs or HIV, and thus, may decide not to get screened. In South Africa, for instance, women often believe that a positive screening test means that they have AIDS. ${ }^{19}$ This view also prevailed in Kenya where cervical screening often is confused with the "AIDS test" or with STI testing because women have been told that cervical cancer is caused by 
Table II

\section{SPECIAL STUDIES ON WOMEn's EXPERIENCES UNDERTAKen WITHIN EACH ACCP PROJECT}

Alliance partner/Name of project

EngenderH ealth

1) "Screen and Treat" Clinical Trial

2) CHIP Project
Special studies

Study objective:To examine women's experiences with cervical screening and treatment with cryotherapy and ability to comply with post-cryotherapy experiences. ${ }^{19}$

Methods:A total of 127 interviews, 15 focus groups, and two patient workshops were carried out among women who did not attend screening, women who were screened, and women treated with cryotherapy.

Study objective:To examine test characteristics for both VIA and HPV DNA testing, clinical experiences, and post-treatment compliance. ${ }^{2}$

Methods: Follow-up interviews were conducted with screened and treated women ( $N=2754$ ).

Study objective: Randomized study of different media interventions (comic and radio play), undertaken to determine whether either intervention resulted in uptake of cervical cancer screening. ${ }^{21}$

Methods: Data were collected by questionnaires administered to women in a random cluster design study $(\mathrm{N}=664)$.

\begin{tabular}{|c|c|}
\hline $\begin{array}{l}\text { genderH ealth \& PAHO } \\
\text { Bolivia Project }\end{array}$ & $\begin{array}{l}\text { Study objective:To assess existing screening and treatment services at primary, secondary, and tertiary levels in } \\
\text { order to facilitate decision-making for potential improvements in service delivery and quality of care. }{ }^{15} \\
\text { Methods: Key informant interviews ( } \mathrm{N}=583 \text { ) were used to collect data among a variety of stakeholders. }\end{array}$ \\
\hline $\begin{array}{l}\text { PAHO } \\
\text { "Bridging Distances" Special Study }\end{array}$ & $\begin{array}{l}\text { Study objective:To examine specific aspects of women's attitudes and behaviors related to benefits of cervical } \\
\text { screening, importance of screening as an aspect of personal health, types of health care practices, and conversa- } \\
\text { tional structures related to health. } \\
\text { Methods: Meta-analysis of three commissioned PAHO studies carried out in Ecuador, Venezuela, and Mexico } \\
\text { from 1997-1999. Additional data were collected from screened women in El Salvador and Peru. In this analysis, } \\
\text { the sample size consists of a total of } 75 \text { individual interviews and } 23 \text { focus/discussion groups. }{ }^{23}\end{array}$ \\
\hline $\begin{array}{l}\text { PAHO \& PATH } \\
\text { TATI Project }\end{array}$ & $\begin{array}{l}\text { Study objective:To determine client satisfaction and acceptability of services among screened women. }{ }^{15} \\
\text { Methods: Client exit interviews were conducted at health facilities that offered services at 4- to } 5 \text {-month inter- } \\
\text { vals during a } 15 \text {-month period ( } N=1269) \text {. } \\
\text { Study objective:To determine client satisfaction and acceptability of services among cryotherapy patients and } \\
\text { their ability to comply with post-cryotherapy instructions [unpublished reports]. } \\
\text { Methods: U sing a structured questionnaire, a total of } 224 \text { women participated in follow-up interviews } 5 \text { to } 6 \\
\text { weeks after receiving cryotherapy treatment.The total represented } 76 \% \text { of the eligible } 293 \text { women treated over } \\
\text { a 4-month period. }\end{array}$ \\
\hline $\begin{array}{l}\text { ATH } \\
\text { W KCCPP Project }\end{array}$ & $\begin{array}{l}\text { Study objective:To assess community knowledge, attitudes, and experiences with cervical cancer prevention.18 } \\
\text { Methods: A total of } 27 \text { focus groups and } 18 \text { key informant interviews carried out among key male and female } \\
\text { opinion leaders in communities that were to receive new services. } \\
\text { Study objective:To examine women's experiences with cryotherapy and ability to comply with post-cryotherapy } \\
\text { instructions. } \\
\text { Methods: } U \text { sing a semi-structured questionnaire, } 22 \text { women (100\%) who had received cryotherapy over a } 15- \\
\text { month period participated in follow-up interviews. }\end{array}$ \\
\hline
\end{tabular}

Study objective:To assess existing screening and treatment services at primary, secondary, and tertiary levels in order to facilitate decision-making for potential improvements in service delivery and quality of care..$^{15}$ Study objective:To examine specific aspects of women's attitudes and behaviors related to benefits of cervical tional structures related to health.

Methods: Meta-analysis of three commissioned PAHO studies carried out in Ecuador, Venezuela, and Mexico from 1997-1999. Additional data were collected from screened women in El Salvador and Peru. In this analysis, Study objective:To determine client satisfaction and acceptability of services among screened women. ${ }^{15}$ Methods: Client exit interviews were conducted at health facilities that offered services at 4- to 5-month interStudy objective:To determine client satisfaction and acceptability of services among cryotherapy patients and -month period.

Methods: Using a semi-structured questionnaire, 22 women (100\%) who had received cryotherapy over a 15 meriod participated in follow-up interviews. human papillomavirus (HPV). In Kenya, HIV/AIDS is heavily stigmatized and treatment is largely unavailable. ${ }^{18}$ Further, positive STI test results often are viewed as proof of marital infidelity. Because of these stigmas, some women are especially fearful about explaining the results of these examinations to their spouses, and therefore may decide not to be screened.

On the other hand, some women may see added benefits to cervical screening because other ailments can also be treated. This is the case where cervical screening is part of a broader group of women's reproductive health services. ACCP researchers in Bolivia found that some women refused Pap smear screening because they believed that it is a diagnostic tool for any vaginal/gynecological problem. On the other hand, women in Bolivia who did go for screening perceived the benefit in terms of receiving an STI diagnosis only, because vaginal discharges also were treated during the same visit. In South Africa, of 69 women interviewed who had come for cervical screening, 52 reported after probing that they had actually came because they perceived they had a "womb-related ailment" ${ }^{19}$ In some clinics, however, providers reported that this perceived benefit has resulted in the same 
women getting Pap smears as often as every three to six months, which results in an inefficient use of scarce resources.*

Fears stemming from negative images of cancer and gynecological care. Women interviewed in a variety of countries reported having powerful and quite frightening images of cancer. These fears may contribute to a woman's reluctance to get screened. Images are associated with words such as "devour or eating", "putridity", or "plague". ${ }^{23}$ For example, in Mexico, terms used to describe cervical cancer included "rotting or devouring of the womb". ${ }^{22}$ Women in Kenya describe the inevitability of cervical cancer and the belief that, at a minimum, the womb will be "cut out", resulting in the loss of womanhood and sexuality. ${ }^{18}$ In Mexico, women reported a fear that any treatment would leave them "hueca" (sexually disabled), ${ }^{22}$ and in Bolivia, women stated that cancer is a "death sentence" that destines them to die slowly and painfully.*

In South Africa, the pelvic examination is referred to as "hanging the legs" and women refer to the experience as "surrendering oneself" ${ }^{19}$ In this setting, a cervical examination is especially problematic because, unlike a pregnancy-related exam (which is viewed favorably by the community), a positive cervical screening test implies that she is somehow "dirty" or promiscuous. ${ }^{19}$ It also challenges the male partner's "ownership" of and control over his wife. ${ }^{19}$

The need for social support. ACCP research to date suggests that women are more likely to be screened (and treated if needed) when services are offered through face-to-face visits by community health workers or when they hear about services through a women's or church group. In one South African project, women reported enjoying group information sessions, knowing they could bring their friends and neighbors, and feeling that health care educators or providers (who run the sessions) really cared about them. ${ }^{19}$ Indeed, in this setting, women often came to the health facility once or twice with a friend to learn about the service before they agreed to be screened. This allowed them to be convinced of the need for "taking care of one's womb" (i.e., preventive health).

Another key factor in a woman's decision to participate in cervical cancer prevention services is her husband's positive emotional and, if needed, financial support. For instance, in Kenya, community health

\footnotetext{
* Bolivia Ministry of Health, EngenderHealth, Pan American Health Organization. Los servicios de prevención y control de cáncer del cuello del útero: Un diagnóstico estratégico, Informe final. Unpublished report available from EngenderHealth, New York.
}

workers noted that many women do not seek cervical screening services or make follow-up visits because their husbands provide little support or are actively opposed. ${ }^{17}$

\section{Barriers related to the service delivery system}

Location of service. For some women, especially those living in communities where there is minimal access to health care, the location of the service facility is an important determinant of participation. Geographic inaccessibility remains a central barrier in most resource-poor settings, as a significant portion of the population at risk for cervical cancer may be located in areas where little or no coverage currently exists. ${ }^{23}$ In Peru, ACCP researchers have found that screening rates were much lower in districts where services were distant or difficult to access. Conversely, regional coverage rates were much higher where static services were more accessible to major population centers or where mobile campaigns brought services to women. In Nayarit, Mexico, and in Western Kenya, women reported that transportation costs and distance played a significant role in screening participation and loss to follow-up..$^{22,17}$ In these rural areas, there is no public transport and women must pay for private transportation. Kenyan studies also show that many women must travel anywhere from two to eight hours, at an average cost of a day's agricultural wage. ${ }^{17,18} \mathrm{Commu-}$ nity health workers in Kenya reported that some male partners do not permit their wives to seek screening because they do not want them traveling long distances, which often requires travel at night. ${ }^{17}$ Women come to clinics only when they are able to finance the trip, negotiate their home responsibilities, and obtain support from their husbands. When women do make the trip, they are not as likely to return if they are turned away or otherwise unable to be seen.

Structure of the service delivery system. Cervical cancer prevention efforts around the world require multiple visits for screening, confirmatory diagnosis, treatment, and follow-up, compounding both financial and opportunity costs to women and contributing to high attrition rates. A key ACCP goal has been to investigate the safety, efficacy, and acceptability of clinical approaches that reduce the overall number of visits. For example, efforts in Peru to reduce loss to follow-up have included increasing the number of mobile campaigns to distant communities, offering screening and immediate treatment during the same visit, improving the referral system, and seeking out women who have not returned for follow-up. 
In Bolivia, functioning tracking systems that ensure clients continue with treatment or additional visits are rare, and attrition is high. In one Bolivian hospital, approximately 50 percent of the women requiring treatment for precancer never received it. In order to address this problem, screening, diagnosis and treatment (conization) of precancer is provided to women aged 25 to 49 at no cost in government facilities, making additional care more accessible to women in this age group.*

Need for information on cost of services and related costs. Women often do not receive accurate information about the actual costs of services. In Bolivia, the availability of free screening and selected treatments for women aged 25 to 49 has improved women's access to services by up to $200 \%$ in some regions, but many women still do not know that these services are free. ${ }^{*}$ Furthermore, providers often do not offer Pap screening unless a woman requests it. In Kenya, community health workers inform women in advance of the exact costs of screening services and of transport to clinics. They also advise women to bring extra money to clinics in case they have to purchase medication for other health problems. ${ }^{17}$

Barriers related to post-treatment care. Where cryotherapy is used as the main method of treatment for precancerous cervical lesions, compliance with clinical requirements may be difficult for women and their partners without proper counseling. Women who receive cryotherapy treatment often defer or fail to return for follow-up appointments. Reasons include lack of funds for transport, lack of support by husbands to attend follow-up visits, fears of what would happen if they returned, and lack of qualified providers at the time of the visit.

In each of the ACCP projects that offers cryotherapy, women are given instructions regarding infection control, management of treatment side effects, and follow-up appointments. As a key approach to reduce risk of infection, women are instructed to abstain from sexual relations for one month, or to use a condom if abstention is not possible. They also are told to report back to the health facility if they experience any side effects. For women who have been treated, follow-up visits generally are recommended at one, three, or six months post-treatment, followed by an annual visit. To sup-

\footnotetext{
* Bolivia Ministry of Health, EngenderHealth, Pan American Health Organization. Los servicios de prevención y control de cáncer del cuello del útero: Un diagnóstico estratégico, Informe final. Unpublished report available from EngenderHealth, New York.
}

port women in voluntarily adhering to these recommendations, they are given condoms, counseling, and easy-to-understand take-home instructions aimed at educating male partners.

In the Khayelitsha project in South Africa, followup studies of women who were treated with cryotherapy show that most women seemed to fully understand the need for abstinence and the importance of healing. Most women experienced cryotherapy-associated vaginal discharge and viewed it as "cleaning out the vagina"; they believed that they should abstain until they were "completely cleaned out." Researchers, however, found that giving condoms to women led to mixed results -some partners liked this strategy, while it led others to think the woman had been unfaithful. ${ }^{19}$

ACCP researchers recently conducted two special studies in which 23 women in Kenya and 224 women in Peru were interviewed after receiving cryotherapy to assess their ability to adhere to post-treatment recommendations. ${ }^{17}$ Findings indicated that women were less likely to follow instructions when they did not understand what they were being asked to do or did not recognize the importance of the recommendations. Women also were less likely to follow instructions when they received little or no post-treatment counseling. Significantly, partner support was cited as a key reason for adherence to clinical guidelines. Most women were able to abstain from sex or use a condom, although some reported that they were unable to fully comply because they were coerced into having sexual relations, or they were unable to obtain condoms. In some instances, men sought sexual partners elsewhere during this time period. Women with supportive partners reported that their husbands provided funds for transport and encouragement to attend follow-up visits. Some women commented that their husbands gave them permission to rest (abstaining from sex and taking time away from heavy labor) after the treatment procedure and helped with household chores. ${ }^{17}$ This highlights the importance of including male partners in post-treatment counseling when possible.

Barriers for women needing more advanced care. In all project settings, women with difficult-to-treat cervical lesions or with cervical cancer are referred for additional care at tertiary care centers. In low-resource settings, the availability of treatment and trained staff often is limited or difficult to access, and appropriate care often is unaffordable. Some type of external financial assistance for cancer care generally is necessary for poor women living in inaccessible communities to access cancer care. Cancer treatment centers are often found in large urban areas, and expenses add up quickly for women living in peripheral regions, as it may 
require several days of travel as well as weeks of lodging while receiving treatment. Recognizing the difficulties that women face in receiving treatment services for cervical cancer, the TATI project in northern Peru has linked with the Peruvian Cancer Foundation to raise funds to support women who must travel to Lima from distant locations to receive care.

\section{Barriers related to quality of care}

The need for women-centered quality services. ACCP projects share a common goal to support the development of client-centered, high-quality services. ${ }^{13,15,24,25}$ Such services result in satisfied women, who, in turn, are strong promoters of screening. These women also provide needed support to those having difficulty deciding whether to participate or whose male partners are unwilling to provide support. ${ }^{23}$

The client-provider relationship greatly affects client satisfaction. ${ }^{23,25}$ For example, the conditions under which counseling takes place, how effectively and respectfully the provider communicates information to the woman, the woman's ability to ask questions, the process of informed consent, and the respect for privacy and confidentiality all are important factors that influence a woman's experience with care. Screened women interviewed in Peru, Kenya, Mexico, and South Africa highlighted the importance of providers taking time to converse with them, answering questions, explaining procedures, and giving encouragement. ${ }^{15,17,19,22}$ Women appreciated being addressed by their names, and wanted providers to speak simply, softly, and gently, and avoid brusque behavior. Non-Spanish-speaking indigenous women who were interviewed in the Nayarit study highlighted the importance of having an interpreter available at the clinic, as many do not seek services because of the language barrier. $^{23}$

Women also expressed the need for confidentiality. Women who have been screened commonly report feeling ashamed, especially when privacy is lacking or when male providers performed the examination. They also report being embarrassed by having to expose their genitals or be touched by a stranger. Cultural norms regarding the circumstances in which it is appropriate for revealing one's body must be negotiated before the idea of a cervical examination can be accepted. In Kenya, for example, some women live in Muslim communities where it is forbidden for women to expose themselves to anyone except their husbands. In some instances, male partners have agreed to their wives' receiving the service only if a female provider performs the examination. ${ }^{17}$
One-on-one communication between women and their providers is a critical dimension of quality care that often is overlooked. ${ }^{13}$ Interviews with women in Kenya and South Africa indicated that they generally were reluctant to openly ask questions during group counseling sessions. ${ }^{17,19}$ They reported that individual time was needed with the provider to ask potentially embarrassing questions about the procedures, address additional fears about adverse effects, and seek advice on how to talk to their spouses.

Physical aspects of the facility. Other important dimensions of quality of care are the physical aspects of the facility, such as the appearance and cleanliness of the clinic and provider, and arrangements to assure maximum privacy during the examination. For example, women in Kenya reported that they had more confidence in a provider who had clean and pressed clothing, a clean appearance, clean instruments, and clean linen on the examination table. ${ }^{17}$ Client satisfaction study data from Kenya and Peru showed that women realized the same specula were used with many women and that their common concern was that the specula were not properly cleaned before being used. To address this, Kenya clinical practices were adjusted so women actually see the speculum being taken from the "clean" room before use and put into soapy water and then a decontamination solution after use. Women in several settings also suggested improving privacy by minimizing the number of people coming into the examination room, having a dead bolt on a door, or having a privacy screen set up during the examination.

\section{Discussion}

Those involved in planning and delivering cervical cancer prevention services must have a clear understanding of the needs, concerns, and beliefs of women and communities to ensure that services will be accessible, acceptable, and utilized. A key step to achieving optimal coverage is to gain broad community support. ${ }^{21,22,26}$ Communication strategies for raising awareness about services and encouraging participation need to be developed with community input by carrying out formative research during the planning stage of program initiatives. Messages need to use words and phrases that are understood locally. ${ }^{25}$ Messages also should reflect the real concerns that women have about services, how communities view preventive care in general, and local understanding of screening procedures and of cancer. Community surveys or focus groups with potential clients and their male partners and meetings with key opinion leaders, 
women's groups, and churches also are important ways to ensure community input. ${ }^{18,21,25}$

Health care service delivery systems that provide cervical cancer prevention services need to be flexible in responding to the needs of the client population. ${ }^{13} \mathrm{~A}$ well-run program will invest in gathering input from women on the most acceptable hours of operation..$^{18}$ Effective programs also will work with community leaders to develop innovative strategies (such as mobile campaigns) for delivery of services to hard-to-reach women. ${ }^{27}$ These measures also will reduce attrition, as will having strong follow-up protocols in place that can track and effectively motivate women to return for follow-up. ${ }^{12,17}$ In addition, programs with effective information systems that link to communities are better able to notify potential clients of any changes or interruptions to routine service delivery systems. ${ }^{1,11}$

Cervical screening programs in low- and middleincome settings also face the challenge of reducing over-utilization of screening services by women in their teens and twenties, who are not as likely to develop cervical cancer as older women (aged 30-50). 1,7,25,28 This problem can be addressed by: a) better educating providers on the natural history of cervical cancer; b) reassuring providers that frequent screening of young women (especially under 25) is not a good use of resources; and c) prioritizing services for older women so that cervical cancer rates will, in fact, be reduced. $1,7,11,17$

A flexible and well-run program must also implement strategies for ensuring quality control of screening and treatment procedures. ${ }^{24}$ It will have a system for maintaining a consistent supply of equipment and supplies (including condoms for women who have undergone cryotherapy) ${ }^{17,24}$ and adequately trained staff, especially where staff turnover is high. ${ }^{25}$ Programs must try to ensure that facilities are clean and welcoming and provide adequate privacy for clients. ${ }^{17,25}$ Programs also will benefit from implementing a client feedback process that can readily identify and address women's emerging concerns that may influence whether a woman decides to be screened..$^{15}$ These actions should reduce interruption of services, improve the quality of care, and assure maximum participation.

An ongoing quality-of-care training program for health care providers is essential for improving service delivery. ${ }^{13,16,24}$ Training can help health workers understand the importance of a satisfied client and develop goals for improving performance. Training should help participants develop good counseling skills and understand client concerns and rights. ${ }^{26}$
Training also should focus on how providers can communicate most effectively with men to encourage them to support their partners through the process of cervical screening and treatment, if needed.

Although many of these steps will require some additional investment, the benefits should justify the modest added costs. Eliminating the most critical barriers that affect women's participation in cervical cancer prevention programs, as well as identifying and supporting conditions that encourage women's use of services, should result in programs that are acceptable and accessible to women, thereby increasing participation rates and ultimately reducing the cervical cancer disease burden. Furthermore, adjusting services to better meet women's needs not only will lead to improved cervical cancer services, but also to improved reproductive health services overall.

\section{Acknowledgments}

The authors acknowledge Deirdre Campbell and Kristin Dahlquist for their input in document preparation.

\section{References}

1. Sankaranarayanan R, Budukh AM, Rajkumar R. Effective screening programmes for cervical cancer in low- and middle-income developing countries. Bull W orld Health 0 rgan 2001;79(10):954-962.

2. D enny $L, K$ Kunn $L$, Pollack $A, W$ ainwright $H, W$ right TC Jr. Evaluation of alternative methods of cervical cancer screening for resource-poor settings. Cancer 2000;89(4):826-833.

3. C uzick J, Sasieni P, D avies P,A dams J, N ormand C, Frater A, et al.A systematic review of the role of human papillomavirus (HPV) testing within a cervical screening programme: Summary and conclusions. $\mathrm{Br}$ J Cancer 2000;83(5):561-565.

4. Belinson JL, Pretorius RG , Z hang W H, W u LY, Q iao YL, Elson P.

Cervical cancer screening by simple visual inspection after acetic acid. 0 bstet Gynecol 2001;98(3):441-444.

5. University of Zimbabwe//H PIEG O Cervical C ancer Project.Visual inspection with acetic acid for cervical cancer screening: Test qualities in a primary-care setting. Lancet 1999;353(9156):869-873.

6. Wesley R, Sankaranarayanan R, Mathew B, Chandralekha B, AyshaBeegum A, Amma N S. Evaluation of visual inspection as a screening test for cervical cancer. Br J C ancer 1997;75(3):436-440.

7. Pan A merican Health $\mathrm{O}$ rganization (PAHO).Timely detection of cervical cancer. Bull Pan Am Health O rgan 1996;30(4):285-289.

8. Pan A merican H ealth 0 rganization. Cervical cancer: Fighting a leading killer in the Americas [Press release].W ashington D.C.: PAHO February 7, 2002. Available online at: www.paho.org.

9. Brown AD, Garber AM. C ost-effectiveness of 3 methods to enhance the sensitivity of Papanicolaou testing. JA MedA 1999;281(4):347-353. 10. Pap smears: An important but imperfect screening method. Cervical cancer prevention fact sheet. Seattle (W A): Program for Appropriate Technology in Health (PATH): February 2001. 
11. Lazcano-Ponce EC, Moss S, de Ruiz PA, C astro JS, Hernández-Avila, $M$. Cervical cancer screening in developing countries: $W$ hy is it ineffective? The case of Mexico. Arch Med Res 1999;30:240-250.

12. Miller $A$, Robles S.W orkshop on screening for cancer of the uterine cervix in Central America. Bull Pan Am Health $O$ rgan (PAHO) 1996; 30(4):397-408.

13. Herdman C, Sherris J. Planning appropriate cervical cancer prevention programs. $2^{\text {nd }}$ edition. Seattle (W A): Program for Appropriate Technology in Health (PATH), 2000.

14. Fylan F. Screening for cervical cancer:A review of women's attitudes, knowledge, and behavior. Br J G en Pract 1998;48:1509-1514.

15. Bingham A, Lagos G,W inkler J, Palomino A. Monitoring quality of care in cervical cancer prevention services: A client feedback process. Presented at the $29^{\text {th }}$ Annual G lobal Health Conference; 2002; W ashington, DC, USA.

16. W inkler JL, Bingham A, Bishop A, Ferreccio C, D el A guila R, G onzáles $M$ et al. D eveloping sustainable community strategies for promoting the prevention of cervical cancer. Presented at the $19^{\text {th }}$ International Papillomavirus Conference; 2001 September 1-7; Florianópolis, Brazil.

17. Program for A ppropriate Technology in Health (PATH).

Proceedings of the W estern Kenya C ervical $C$ ancer Prevention Project (W KCCPP) dissemination workshop; 2002, March 7. N airobi, Kenya. Copies of this report are available by contacting: accp@ path.org or by writing: Cervical C ancer Prevention Team, PATH, 1455 N W Leary W ay, Seattle (W A), 98107 USA.

18. Bingham A, A bwao S, Luchemo N . Formative research in cervical cancer prevention in Kenya:The W estern Kenya Cervical Cancer Prevention Project. Roundtable discussion, $28^{\text {th }}$ Annual Global Health Conference; 2001 May 29-June 1;W ashington, DC, USA.

19. Buskens I, Bradley J.W omen's perspectives on cervical cancer prevention procedures. N ew York: EngenderH ealth, 2002.
20. D enny $L, K u h n ~ L$, Pollack $A, W$ right TC. D irect visual inspection for cervical cancer screening: $A n$ analysis of factors influencing test performance. Cancer 2002;94(6):1699-1707.

21. Risi L, Bindman JP, C ampbel O MR, Inhrie J, Everet K, Bradley J et al. Media interventions to increase cervical screening uptake in South Africa: Study of effectiveness. Health Educ res (In press).

22. Program for A ppropriate Technology in Health (PATH). Q ualitative assessment of the knowledge, attitudes, and practices regarding cervical cancer among selected women and providers in N ayarit State, Mexico. Seattle (W A): PATH, 1998.

23. A gurto I. Bridging distances: Preventive services and women's concerns. Program on N on-C ommunicable Diseases, Division of D isease Prevention and Control.W ashington, DC: Pan A merican Health 0 rganization, 2001.

24. AVSC International. CO PE: C lient-oriented, provider-efficient services: A process and tools for quality improvement in family planning and other reproductive health services. N ew York:AVSC International, 1995.

25. Lazcano-Ponce EC, Castro R,Allen B, Nájera P, Alonso de Ruiz PA, Hernández-A vila M. Barriers to the early detection of cervical-uterine cancer in Mexico. J Women's Health 1999;8(3):399-408.

26. Álvarez S. Knowledge and fears among Chilean women with regard to the Papanicolaou test. Bull Pan Am Health O rgan (PAHO) 1996:30(4): 354-361.

27. Swaddiwudhipong W, C haovakiratipong C, N guntra P, Mahasakpan P, Tatip Y, Boonmak C.A mobile unit:An effective service for cervical cancer screening among rural Thai women. Int J Epidemiol 1999;28:35-39.

28. Robles $S, W$ hite $C F$, Peruga A. Trends in the cervical cancer mortality in the Americas. Bull Pan Am Health O rgan 1996;30(4):290-301. 